\title{
PEMBERDAYAAN REMAJA BERBASIS MASJID (Studi Terhadap Remaja Masjid Di Labuh Baru Barat)
}

\author{
Aslati $^{1}$, Silawati ${ }^{2}$, Sehani $^{3}$, Nuryanti $^{4}$ \\ ${ }^{1,2,3,4}$ Jurusan Pengembangan Masyarakat Islam Fakultas Dakwah dan Komunikasi \\ Universitas Islam Negeri Sultan Syarif Kasim Riau \\ Email:aslati@uin-suska.ac.id
}

\begin{abstract}
Abstrak
Tujuan dari Pemberdayaan Remaja Masjid adalah untuk menggali sumberdaya remaja yang lahir dari program-program yang berbasis Masjid agar terwujud remaja yang berakhlak mulia dan Qurani.Istilah Remaja Masjid tidak asing bagi umat Islam di Indonesia.Remaja Masjid adalah organisasi yang mewadahi aktivitas remaja muslim dalam memakmurkan Masjid, yang berorientasi pada aktivitas kemasjidan, keislaman, keilmuan, keremajaan dan keterampilan, organisasi ini dapat memberikan kesempatan bagi anggotanya mengembangkan diri sesuai bakat dan kreativitas mereka di bawah pembinaan Pengurus/Ta'mir Masjid.Metode pemberdayaan adalah Participatory Action Research (PAR). Hasil dari kegiatan pemberdayaan adalah Remaja diajak untuk mengembangkan diri melalui Pelatihan kepemimpinan dan Organisasi serta mengaplikasikan program yang sudah dirancang seperti pengembangan usaha ekonomi kreatif berbasis kerajinan tangan dan dijual di warung-warung, swalayan, sekolahsekolah.
\end{abstract}

Kata Kunci: Pemberdayaan, Remaja, Masjid

\section{Pendahuluan}

Tinjauan Historis tentang fungsi masjid pada masa Rasulullah bahwa masjid memainkan peranan yang sangat luas. Masjid berfungsi sebagai tempat beribadat, seperti shalat dan zikir, sebagai tempat pendidikan, tempat pemberian santunan sosial, tempat latihan militer dan persiapan perang, tempat pengobatan para korban perang, tempat mendamaikan dan menyelesaikan sengketa, tempat menerima utusan delegasi/tamu, sebagai pusat penerangan dan pembelaan agama. Dari pembinaan yang dilakukan Rasulullah SAW di masjid itu lahirlah tokoh-tokoh yang berjasa dalam pengembangan Islam ke seantero dunia, seperti Abu Bakar Shiddiq, Umar bin alKhatab, Usman bin 'Affan dan Ali bin Abi Thalib.

Dewasa ini di Indonesia masyarakat muslim seolah-olah berlomba mendirikan masjid. Tentu saja fenomena ini memberi kontribusi positif terhadap kualitas umat Islam .Peningkatan kualitas umat Islam melalui masjid dilakukan dalam rangka meningkatkan keimanan, keilmuan dan amal shaleh.Sejatinya masjid tidak saja dijadikan oleh kaum tua untuk beri'tikaf namun harus bisa dijadikan sebagai daya 
tarik bagi kaum muda untuk mengisi hari-hari mereka dengan kegiatan edukasi dalam rangka memakmurkan masjid tersebut. Allah SWT berfirman:
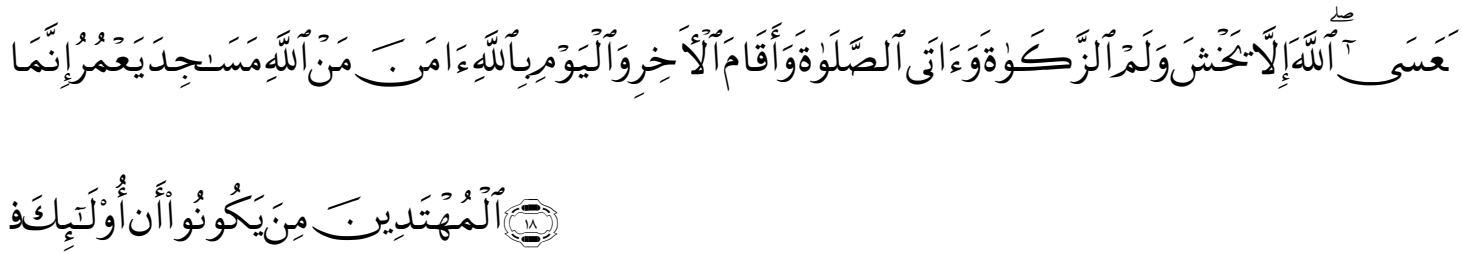

"Hanya yang memakmurkan masjid-masjid Allah ialah orang-orang yang beriman kepada Allah dan hari Kemudian, serta tetap mendirikan shalat, emnunaikan zakat dan tidak takut (kepada siapapun) selain kepada Allah, Maka merekalah orangorang yang diharapkan Termasuk golongan orang-orang yang mendapat petunjuk”. (QS. At-Taubah: 18)

Kedudukan remaja terhadap masjid memiliki peran yang sangat penting. Dalam konteks kemasjidan, generasi muda menjadi tulang punggung dan harapan besar bagi kemakmuran masjid pada masa kini dan mendatang.Rasulullah SAW bersabda: "Ada tujuh golongan orang yang akan dinaungi Allah yang pada hari itu tidak ada naungan keculi dari-Nya yaitu: pemuda yang perkembangan hidupnya senantiasa beribadah (taat) kepada Allah dan seseorang yang hatinya terpaut dengan masjid ketika ia keluar hingga kembali padanya”.(HR. Bukhari Muslim).

Istilah Remaja Masjid tidak asing bagi umat Islam di Indonesia.Remaja Masjid adalah organisasi yang mewadahi aktivitas remaja muslim dalam memakmurkan Masjid. Remaja Masjid merupakan salah satu alternatif wadah pembinaan remaja yang baik dan dibutuhkan umat.Dengan berorientasi pada aktivitas kemasjidan, keislaman, keilmuan, keremajaan dan keterampilan, organisasi ini dapat memberikan kesempatan bagi anggotanya mengembangkan diri sesuai bakat dan kreativitas mereka di bawah pembinaan Pengurus/Ta'mir Masjid.Saat ini Remaja Masjidtelah menjadi wadah lembaga kegiatan yang dilakukan para remaja muslim di lingkungan Masjid. Di kota-kota maupun di desa-desa, dapat dijumpai dengan mudah. Organisasi Remaja Masjid juga telah menjadi suatu fenomena bagi kegairahan para remaja muslim dalam mengkaji dan menda'wahkan Islam di Indonesia. Masyarakat juga sudah semakin lebih bisa menerima kehadiran mereka dalam memakmurkan Masjid. Disadari bahwa untuk memakmurkan Masjid diperlukan organisasi yang mampu beraktivitas dengan baik. Organisasi Remaja Masjid 
memerlukan para aktivis yang mumpuni dan profesional.Kehadiran mereka tidak bisa serta merta, tetapi perlu diupayakan secara terencana dan terarah melalui sistem perkaderan khususnyamelaluipelatihan-pelatihanyangsangat mendukung.

Kepemimpinan adalah sebuah gaya dan seni dalam menjalankan dan menggerakkan roda organisasi menuju arah dan visi yang ditetapkan. Pemimpin dalam peran manajemen cenderung menghadapi situasi yang menantang.Pemimpin sering mencari strategi terbaik agar dapat bekerja dalam semua situasi. Oleh karena itu memimpin berarti siap menjadi pemimpin yang visioner, memberdayakan, memotivasi, memfasilitasi, mendorong, berkomunikasi secara efektif, membangun kepercayaan, memimpin dengan nilai-nilai terbaik, menyelesaikan konflik dan kharismatik untuk mengatasi setiap situasi dan kondisi yang penuh dinamika dalam menuju perubahan.

Mempertimbangkan pentingnya hal tersebut maka diperlukan sebuah pelatihanLeadership dan organisasi bagi Remaja Masjid sehingga nantinya para remaja mempunyai sikap yang sigap, tegas dan bertanggung jawab dalam menyelesaikan masalah-masalah yang ada di lingkungan Masjid.Pelatihan ini dirancang untuk pembinaan Remaja Masjid melalui peningkatan wawasan ke-Islaman dan keterampilan berorganisasi.Remaja dalam hal ini tidak saja ditujukan kepada remaja laki-laki namun dalam hal kepemimpinan dan organisasi juga diperlukan peran remaja perempuan dalam menggerakkan tujuan dari organisasi tersebut.

\section{Kajian Pustaka}

\section{Makna Revitalisasi}

Revitalisasi adalah upaya untuk memvitalkan kembali suatu kawasan atau bagian kota yangdulunya pernah vital/hidup, akan tetapi kemudian mengalami kemunduran/degradasi. Skalarevitalisasi ada tingkatan makro dan mikro. Proses revitalisasi sebuah kawasan mencakupperbaikan aspek fisik, aspek ekonomi dan aspek sosial. Pendekatan revitalisasi harus mampumengenali dan memanfaatkan potensi lingkungan (sejarah, makna, keunikan lokasi dan citratempat) (Danisworo, 2002).Revitalisasi sendiri bukan sesuatu yang hanya berorientasi padapenyelesaian keindahan fisik saja, tapi juga harus dilengkapi dengan peningkatan ekonomimasyarakatnya serta pengenalan budaya yang ada.Untuk melaksanakan 
revitalisasi perlu adanyaketerlibatan masyarakat.Keterlibatan yang dimaksud bukan sekedar ikut serta untuk mendukungaspek formalitas yang memerlukan adanya partisipasi masyarakat, selain itu masyarakat yangterlibat tidak hanya masyarakat di lingkungan tersebut saja, tapi masyarakat dalam arti luas.(Laretna, 2002).

\section{Makna Masjid}

Kata "masjid” disebut dalam Al-qur'an sebanyak 28 kali. Kata "masjid” itu adalah bahasa Arab yang berasal dari akar kata "sajada-yasjudu-sujudan” yang berarti tunduk, patuh, ta'at dengan penuh ta'zim dan hormat. Kata "masjid" merupakan isim makan (kata yang menunjukan tempat), maksudnya tempat untuk sujud dengan penuh keta'atan dan kepatuhan. Secara lahiriyah sujud berarti meletakkan tujuh anggota sujud ke tanah ( kening, dua telapak tangan, dua lutut dan dua ujung jari-jari kaki) sebagai bukti nyata dari makna tunduk dan patuh. Karena itu bangunan khusus yang dibuat untuk melakukan sujud(shalat) disebut "masjid". Namun karena akar katanya mengandung makna ta'at, tunduk dan patuh, maka masjid sebenarnya tidak hanya berfungsi sebagai tempat shalat saja, tetapi merupakan the center of activities (tempat melakukan berbagai aktivitas) yang mencerminkan makna ketundukan dan kepatuhan kepada Allah SWT seperti peran dan fungsi masjid di zaman Rasulullah SAW Dalam konteks ini dapat dipahami firman Allah SWT dalam al-Qur'an: "Sesungguhnya masjid-masjid itu adalah milik Allah, karena itu janganlah kamu menyembah/ mengagungkan sesuatupun selain Allah" (QS. Al-Jin: 18).

Dalam Al-qur'an kata "sujud” digunakan untuk beberapa makna, diantaranya bermakna sebagai penghormatan dan pengakuan atas kelebihan pihak lain, seperti perintah Allah kepada Malaikat untuk "sujud” kepada Adam (QS. Al-Baqarah:34). Kata "sujud" juga berarti menyadari kesalahan dan mengakui kebenaran yang disampaikan oleh pihak lain, seperti sujudnya tukang-tukang sihir Fir'aun setelah melihat keunggulan (mu'jizat) Nabi Musa AS.(QS. Thaha;70). Selain itu, kata "sujud" juga bermakna menyesuaikan diri dengan ketentuan-ketentuan Allah SWT Secara yang ada di alam raya ini (sunnatullah), seperti sujudnya bintang-bintang dan pohon (Q.S; Ar-Rahman;55), sujudnya matahari, bulan, bintang, gunung-gunung, pohon-pohon kayu dan binatang-binatang (Q.S. Al-Hajj;18). (Muchlis Bahar: 2012) 


\section{Remaja Masjid}

Pembinaan remaja dalam Islam bertujuan agar mereka menjadi generasi muda yang baik; yaitu anak yang shalih, beriman, berilmu, berketerampilan dan berakhlak mulia. Untuk membina remaja muslim bisa dilakukan dalam berbagai pendekatan, diantaranya melalui aktivitas Remaja Masjid.

Remaja Masjid adalah organisasi yang mewadahi aktivitas remaja muslim dalam memakmurkan Masjid. Remaja Masjid merupakan salah satu alternatif wadah pembinaan remaja yang baik dan dibutuhkan umat. Dengan berorientasi pada aktivitas kemasjidan, keislaman, keilmuan, keremajaan dan keterampilan, organisasi ini dapat memberikan kesempatan bagi anggotanya mengembangkan diri sesuai bakat dan kreativitas mereka di bawah pembinaan Pengurus/Ta'mir Masjid.(Eman Suherman:2012)

Saat ini Remaja Masjid atau dengan sebutan lain telah menjadi wadah lembaga kegiatan yang dilakukan para remaja muslim di lingkungan Masjid. Di kota-kota maupun di desa-desa, dapat dijumpai dengan mudah. Organisasi Remaja Masjid juga telah menjadi suatu fenomena bagi kegairahan para remaja muslim dalam mengkaji dan menda'wahkan Islam di Indonesia. Masyarakat juga sudah semakin lebih bisa menerima kehadiran mereka dalam memakmurkan Masjid.

Disadari bahwa untuk memakmurkan Masjid diperlukan organisasi yang mampu beraktivitas dengan baik. Organisasi Remaja Masjid memerlukan para aktivis yang mumpuni dan profesional.Kehadiran mereka tidak bisa serta merta, tetapi perlu diupayakan secara terencana dan terarah melalui sistim perkaderan, khususnya melalui pelatihan-pelatihan yang sangat mendukung.

Peran remaja masjid:

1. Pendidikan. Remaja mesjid memegang peranan dalam penyebaran budaya islam . Melalui remaja mesjid secara bertahap kita dapat menanamkan nilai - nilai keimanan dasar, sehingga dapat membentengi generasi islam dalam pergaulannya. Sekarang ini seakan tiada batas pergaulan para pemuda,karena itu dengan remaja mesjid inilah kita bisa mengontrol dan mencegah pergaulan bebas yang setiap saat memintai generasi islam kita 
2. Pembentukan jati diri. Dengan pembinaan remaja mesjid kita bisa mengarahkan generasi muda islam untuk mengenal jati diri mereka sebagai muslim.jika mereka sudah mengenal jati diri nya maka mereka tidak akan terombang ambing dalam menentukan jalan hidup mereka

3. Pengembangan potensi. Melalui remaja mesjid kita bisa memotivasi dan membantu generasi muda Islam untuk menggali potensinya mereka serta memotivasi mereka dengan mengadakan kegiatan kegiatan untuk menampilkan kreatifitas mereka. (Zulmaron: 2017)

Pembinaan remaja dalam Islam bertujuan agar remaja tersebut menjadi anak yang shalih; yaitu anak yang baik, beriman, berilmu, berketerampilan dan berakhlak mulia. Anak yang shalih adalah dambaan setiap orangtua muslim yang taat. Sabda Rasulullah shallallahu 'alaihi wa sallam:Apabila anak Adam mati, maka semua amalnya terputus, kecuali tiga: shadaqah jariyah, ilmu yang bermanfaat dan anak yang shalih yang mendoakannya. (HR. Muslim).

Untuk membina remaja bisa dilakukan dengan berbagai cara dan sarana, salah satunya melalui Remaja Masjid,yaitu suatu organisasi atau wadah perkumpulan remaja muslim yang menggunakan Masjid sebagai pusat aktivitas. Remaja Masjid merupakan salah satu alternatif pembinaan remaja yang terbaik.Melalui organisasi ini, mereka memperoleh lingkungan yang islami serta dapat mengembangkan kreatitivitas.

Remaja Masjid membina para anggotanya agar beriman, berilmu dan beramal shalih dalam rangka mengabdi kepada Allah subhanahu wa ta'ala untuk mencapai keridlaan-Nya. Pembinaan dilakukan dengan menyusun aneka program yang selanjunya ditindaklanjuti dengan berbagai aktivitas.Remaja Masjid yang telah mapan biasanya mampu bekerja secara terstruktur dan terencana. Mereka menyusun Program Kerja periodik dan melakukan berbagai aktivitas yang berorientasi pada: keislaman, kemasjidan, keremajaan, keterampilan dan Keilmuan. (Nabed Nuwaerah: 2015)

Mereka juga melakukan pembidangan kerja berdasarkan kebutuhan organisasi, agar dapat bekerja secara efektif dan efisien. Beberapa bidang kerja dibentuk untuk mewadahi fungsi-fungsi organisasi yang disesuaikan dengan Program Kerja dan aktivitas yang akan diselenggarakan, di antaranya:

1. Administrasi dan Kesekretariatan. 


\section{Keuangan.}

3. Pembinaan Anggota.

4. Perpustakaan dan Informasi.

5. Kesejahteraan Umat.

6. Kewanitaan.

Organisasi adalah alat untuk mencapai tujuan.Pencapaian tujuan memerlukan perjuangan yang sungguh-sungguh dengan memanfaatkan segenap sumber daya dan kemampuan.Dalam perjuangan dibutuhkan kesabaran tanpa batas, hanya bentuknya saja yang mengalami perubahan.

Perjuangan yang dilakukan Remaja Masjid adalah dalam kerangka da'wah islamiyah, yaitu perjuangan untuk menyeru umat manusia kepada kebenaran yang datangnya dari Allah subhanahu wa ta'ala. Ada pertarungan antara yang haq dengan yang bathil. Dimana telah diketahui bahwa kebenaran, insya Allah, akan mampu mengalahkan kebathilan. Namun perlu diingat, bahwa di dunia ini kebathilan yang terorganisir juga memiliki peluang untuk dapat mengalahkan kebenaran yang tidak terorganisir karena itu, dalam perjuangan melawan kebathilan perlu persiapan yang sungguh-sungguh dan tertata dengan rapi, seperti “bunyanun marshush".

Untuk membentuk bangunan yang tersusun kokoh (bunyanun marshush) diperlukan organisasi dan management yang tangguh serta didukung sumber daya manusia (SDM) yang mencukupi dan berkualitas.Perekrutan (recruitment) dan kaderisasi anggota sangat diperlukaan oleh Remaja Masjid dalam meningkatkan kuantitas dan kualitas anggotanya.Hal ini dilakukan untuk menjamin kelangsungan aktivitas dan misi organisasi dalam menda'wahkan Islam. Bertambahnya anggota akan menambah semangat dan tenaga baru, sedang tersedianya kader-kader yang berkualitas akan mendukung suksesnya estafet kepemimpinan organisasi.

Remaja muslim adalah unsur utama organisasi Remaja Masjid Keberadaan dan keterlibatan mereka dalam organisasi dapat dibedakan sebagai kader, aktivis, partisipan dan simpatisan. Pengurus perlu meningkatkan kuantitas dengan melakukan:

a) Melakukan pendaftaran (regristrasi) anggota.

b) Mendaftar remaja muslim warga baru. 
c) Melakukan penyadaran kepada remaja muslim yang belum menjadi anggota, agar mereka mau bergabung dalam wadah bersama.

Peningkatan kualitas yang dilakukan adalah untuk meningkatkan keimanan, keilmuan dan amal shalih mereka. Hal itu dilakukan dengan melakukan proses kaderisasi yang dilakukan secara serius, sistimatis dan berkelanjutan, melalui jalur: pelatihaan, kepengurusan, kepanitiaan dan aktivitas . Dalam proses pengkaderan dilakukan upaya-upaya penanaman nilai-nilai, akhlaq, intelektualitas, profesionalisme, moralitas dan integritas Islam. Sehingga diperoleh kader ideal Remaja Masjid yang memiliki profil : remaja muslim yang beriman, berilmu dan berakhlaq mulia yang mampu beramal shalih secara profesional serta memiliki fikrah Islam yang komprehensif.

Sebagai generasi muda muslim pewaris Masjid, aktivis Remaja Masjid seharusnya mencerminkan muslim yang memiliki keterikatan dengan tempat beribadah umat Islam tersebut. Sikap dan perilakunya islami, sopan-santun dan menunjukkan budi pekerti yang mulia (akhlaqul karimah).Pemikiran, langkah dan tindak-tanduknya dinafasi oleh nilai-nilai Islam.Mereka berkarya dan berjuang untuk menegakkan kalimat Allah dalam rangka beribadah mencari keridlaan-Nya.Allah SWT menjadi tujuannya dan Rasulullah menjadi contoh tauladan dan sekaligus idolanya. Gerak dan aktivitasnya berada dalam siklus: beriman, berilmu, beramal shalih dan ber'amar ma'ruf nahi munkar, menuju kesuksesan dan kebahagiaan fid dunya wal akhirah.

Beberapa sikap dan perilaku praktis yang perlu diperhatikan aktivis Remaja Masjid berkaitan dengan aktivitasnya di Masjid, antara lain adalah:

a) Menyadari sebagai pemakmur Masjid.

b) Mengamalkan adab sopan santun di Masjid.

c) Rajin melaksanakan shalat berjama'ah di Masjid.

d) Berpakaian yang islami.

e) Menjaga pergaulan antara laki-laki dan perempuan.

f) Mengembangkan kepribadian yang menarik.

g) Rajin menuntut ilmu.

h) Berusaha terlibat dalam kepengurusan Remaja Masjid. 
Sebagaimana telah kita ketahui, bahwa Remaja Masjid adalah organisasi yang menghimpun remaja muslim yang aktif datang dan beribadah shalat berjama'ah di Masjid. Karena keterikatannya dengan Masjid, maka peran utamanya tidak lain adalah memakmurkan Masjid. Ini berarti, kegiatan yang berorientasi pada Masjid selalu menjadi program utama.Di dalam melaksanakan perannya, Remaja Masjid meletakkan prioritas pada kegiatan-kegiatan peningkatan keislaman, keilmuan dan keterampilan anggotanya.

Aktivitas Remaja Masjid yang baik adalah yang dilakukan secara terencana, kontinyu dan bijaksana; disamping itu juga memerlukan strategi, metode, taktik dan teknik yang tepat.Untuk sampai pada aktivitas yang baik tersebut, pada masa sekarang diperlukan pemahaman organisasi dan management yang baik pula. Adapun jenisjenis aktivitas Remaja Masjid adalah:

a. Berpartisipasi dalam memakmurkan Masjid.

b. Melakukan pembinaan remaja muslim.

c. Menyelenggarakan proses kaderisasi umat.

d. Memberi dukungan pada penyelenggaraan aktivitas Ta'mir Masjid.

e. Melaksanakan aktivitas da'wah dan sosial.

Terkait makna dari Pelatihan adalah Sikula dalam Sumantri (2000:2) mengartikan pelatihan sebagai: "proses pendidikan jangka pendek yang menggunakan cara dan prosedur yang sistematis dan terorganisir. Para peserta pelatihan akan mempelajari pengetahuan dan keterampilan yang sifatnya praktis untuk tujuan tertentu". Menurut Good, 1973 pelatihan adalah suatu proses membantu orang lain dalam memperoleh skill dan pengetahuan (M. Saleh Marzuki, 1992: 5). Sedangkan Michael J. Jucius dalam Moekijat (1990: 2) menjelaskan istilah latihan untuk menunjukkan setiap proses untuk mengembangkan bakat, keterampilan dan kemampuan pegawai guna menyelesaikan pekerjaan-pekerjaan tertentu.

\section{Metode Pelaksanaan Pemberdayan Remaja Masjid}

Adapun Metode pelaksanaan Pemberdayaan bagi Remaja dengan pendekatan Participatory Action Research (PAR), bahwa tim pengabdian mengajak subjek terlibat langsung dalam kegiatan Pemberdayaan. 


\section{Hasil}

Dalam rangka pemberdayaan Remaja berbasis masjid maka kegiatan difokuskan pada pelatihan leadership dan organisasi dilakukan dengan langkah-langkah sebagai berikut:

1) Tim pengabdian mengumpulkan remaja masjid yakni utusan dari masjid-masjid yang ada di Kel. Labuh Baru Barat yang bertempat di Masjid Paripurna yaitu masjid al-Fajar yang beralamat di Jalan Fajar Kel. Labuh Baru Barat.

2) Peserta pelatihan 20 orang yang terdiri dari remaja putra dan remaja putri

3) Materi pelatihan awal yakni tentang dasar-dasar kepemimpinan dan organisasi

4) Penyampaian materi dalam bentuk:
a) Presentasi
b) interaktif
c) Diskusi

5) Diakhir materi diadakan pelatihan usaha ekonomi kreatif membuat kerajinan tangan dan hasilnya dipasarkan di warung-warung terdekat dengan masjid, swalayan dan sekolah-sekolah. Hasil kerajian tanga tersebut berbentuk pernak pernik jilbab.

Setelah diadakan pelatihan maka dampak posistif yang dihasilkan terhadap Remaja Masjid sebagai berikut:

1. Menyadari sebagai pemakmur Masjid.

2. Mengamalkan adab sopan santun di Masjid.

3. Rajin melaksanakan shalat berjama'ah di Masjid.

4. Berpakaian yang islami.

5. Menjaga pergaulan antara laki-laki dan perempuan.

6. Mengembangkan kepribadian yang menarik.

7. Rajin menuntut ilmu.

8. Berusaha terlibat dalam kepengurusan Remaja Masjid.

\section{Kesimpulan}

Setelah diadakan pelatihan dalam rangka pemberdayaan remaja berbasis masjid maka remaja dapat memahami arti penting pemberdayaan dan dapat mengembangkan program-program yang sudah dibuat.Sebagai catatan bahwa perserta pelatihan sangat antusias mengikuti pemaparan materi kepemimpinan dan organisasi, hal ini dibuktikan 
dengan banyaknya pertanyaan dari peserta dan keinginan peserta kedepan supaya pelatihan seperti ini diharapkan dapat berkelanjutan dalam bentuk praktek pengembangan kepemimpinan dan organisasi melalui program-program yang sudah dibuat sebelumnya oleh organisasi remaja masjid tersebut.

\section{DAFTAR PUSTAKA}

Ambar Teguh Sulistiyani, 2004, Kemitraan dan Model-model Pemberdayaan, Gaya Media, Yogyakarta.

Eman Suherman, 2012, Manajemen Masjid: Kiat Sukses Meningkatkan SDM Melalui Optimalisasi Kegiatan Umat Berbasis Pebdidikan Berkualitas, Bandung: Alfabeta Hazzat Nizamuddin, 2003,The Musjid, Its Role and Etquette, edisi Indonesia Peran dan Fungsi Masjid, Yogyakarta:Cahaya Hikmah

Yusuf Al-Qaradhawi, 2000, Adh-Dhawabith Asy-Syar'iyah Libina Al-Masjid, Tuntunan Membangun Masjid, Jakarta: Gema Insani Press

M.Quraish Shihab,1997, Wawasan al-Qur'an, Bandung: Mizan

Moh.E.Ayub, dkk, 1996, Manajemen Masjid, Petunjuk Praktis Bagi Para Pengurus, Jakarta: Gema Insani Press

Nana Rukmana, 2002, Masjid dan Dakwah,Jakarta: Al-Mawardi Prima

Supardi dan Teuku Amiruddin, 2001,Manajemen Masjid Dalam Pembangunan Masyarakat, Yogyakarta: UII Press

Siswanto, 2005, Panduan Praktis Organisasi Remaja Masjid, Jakarta: Pustaka al-Kautsar

Zulmaron Dkk, Peran Sosial Keagamaan Remaja Masjid di Kelurahan Pipa Reja Kecamatan Kemuning Palembang, Jurnal Studi Agama, 2017, vol. 1 No. 1

Nabed Nuwaerah, Peran Keluarga dan Organisasi Remaja Masjid Dalam Dakwah Terhadap Remaja, Jurnal Al-Hiwar, Vol. 03, No. 06, Desember 2015 